\title{
JIHADI MILITANCY IN BAJAUR AGENCY AND ITS IMPACT IN THE AREA
}

\author{
Kiramat Ullah \\ Lecturer, Department of Political Science, \\ Hazara University, Mansehra, Pakistan \\ marwanyousafzai@ymail.com \\ Muhammad Ayaz Khan \\ Associate Professor, Department of Political Science, \\ Hazara University, Mansehra, Pakistan \\ drmuhammadayazkhan@gmail.com \\ Tariq Anwar Khan \\ Lecturer, Department of Political Science, \\ Hazara University, Mansehra, Pakistan \\ tariqanwar84@gmail.com
}

\begin{abstract}
It is undeniable fact that the newly merger District Bajaur in Malakand Division of Pakistan is the victimized of Jehadism, Talibanization and militancy, left indelible imprints on the socio-economic and political lives of the local people. This article aims to focus on the origin; growth of jihadi militancy in the area with special emphasis on the impact of the military operation on Bajaur District of Pakistan. The Paper discusses that how the militants established the F.M radio station for mass mobilization and succeed in the emergence of Tahrik-i-Taliban Bajaur and the rise of militancy in the area. A descriptive method was used in which both primary and secondary sources in the form of Interviews, journals, books, and reports were consulted and reviewed while carrying out this research paper. The article highlights that Maulvi (Muslim religious scholar) Faqeer Muhammad, the vice chief, and some other prominent leaders of Tahrik-i-Taliban Pakistan (TTP) were intended to accomplish the mission of Sufi Muhammad to implement Shariah (Islamic) law through an unlawful and violent armed struggle in Bajaur Agency of Pakistan. In this process, many civilians, government servants, and large numbers of notables were being killed and abducted for ransom. Besides, heavy losses were also reported in the form of severe damages to educational institutions, houses, agriculture, livestock, poultry farms, and small-scale industries. It is concluded from the study that militancy and military operation had a paramount negative impact on the lives of local inhabitants of District Bajaur.
\end{abstract}

Keywords: Taliban, Bajaur, Militancy, Law, Maulvi.

\section{INTRODUCTION}

After the 9/11 incident, Pakistan is the victim of Jihadi militancy and facing a strong threat for its internal security from the local Jihadists (holy fighters) and infiltrators. Pakistan dig its own grave by supporting and motivating the local people for Jihad (holy war) in occupied Kashmir and Afghanistan. The word Jihad is derived from the Arabic word "Juhud" which literal meaning is a struggle or striving. In Islam, the word "Jihad" is a vast phenomenon and has several meanings. It can refer to mold lives in the true shape of Shariah and to do good and forbid evils as it is a sign of a good Muslim or true believer. There is a huge difference between Jihad, which is a continuous struggle or effort for the internal and external good of every Muslim, and Al-Harb, a military action against the infidels, unbelievers, or rebellions. In Islam, if all the peaceful means i-e., political, social, and legal methods to protect the faith are failed and there is no possible solution, then the military action knows as Al-Harb (holy war) is allowed to cope with the matters. In case if the lives and property of the Muslims seem to be under threat or in danger then the competent authorities will issue decrees of war after consulting the matter with religious scholars as no one is allowed to declare war on his behalf. But it must be noted that during the holy war, innocents such as women, children, or disabled must 
never be harmed, their worship places and houses will not be destroyed nor their crops will be burnt, and any peaceful overtures from the enemy must be accepted (Kretsch, 2016).

Besides, in Pakistan the concept of Jihad has been misused by different religious and militant groups. They justify their violence against the government and security forces and have waged war by invoking Jihad on the plea that the Pakistani government is pursuing the will of the Americans and they are the close allies of them and their war is lawful. But on the other hand, some scholars deny their claim, condemn their activities and consider it against the basic principles of Islam (Kretsch, 2016).

The Jihadi militancy in Pakistan trace it roots from October 1947, when the local tribesmen from NWFP went for Jihad against the Maha Raja Heri Singh to support Kashmiri Muslim brothers. Pakistan fought four wars on Kashmir and named these wars as 'Jihads' against the infidels; the participants of wars were praised as martyrs and heroes of Islam and Pakistan. During these wars, the military forces, the highest authorities, and Ulema (scholars) fully supported the Jihadi spirit and motivated the people to take part in Jihad (Haqqani, 2005). Zulfiqar Ali Bhutto also sheltered the Afghan rebel leaders namely Gulbadin Hakmatiyar, Burhanu-Din Rabbani, and Ahmad Shah Masud inside Pakistan and fully funded them to create chaos and problems for president Daud in Afghanistan due to his anti-Pakistani activities. Meanwhile, the USSR invasion in Afghanistan in late 1979 also pave ways for religious groups in Pakistan and Afghanistan, and issued fatwas (decrees) that Jihad is the compulsory obligation of every Muslim and the deniers of the Afghan Jihad are infidels. During the war, more than three million Afghanis fled to Pakistan to save their lives and starting living in tents near the PAK/ AFGHAN bordering areas of Khyber Pukhtunkhwa and Baluchistan. The Central Intelligence Agency (CIA) of America with the help of Inter-Service Intelligence (ISI) of Pakistan took a huge benefit from these refugees and used them against the USSR to defeat them and change the world from Bipolar to Unipolar. The so-called Afghan Jihad also attracted the religious and extremists mind of people from other Islamic world, especially from Gulf countries. Even the CIA published special curriculum books for the Afghan refugees in tent schools to create the zeal of Jihad among these young Afghani students. Pakistan played a front-line state role in the Afghan war and with the help of ISI covertly assisted by the CIA sends a lot of volunteers to fight against the invaders. Different religious groups started military training of the local masses for the Afghan Jihad inside Pakistan near the PAK/ Afghan bordering areas. During this period, the Kalashnikov culture was introduced in Pakistan and other weapons like IEDs and rocket launchers provided by the CIA to the Afghan Mujahedeen (holy fighters) were easily available in the Pakistani market, drug smuggling also started from Afghanistan to Pakistan (Abbas, 2005).

After the USSR withdrawal from Afghanistan, numbers of Pakistani and foreigner mujahedeen came back to tribal areas and Pakistan became the hub of these Jihadist groups (Abbas, 2005). Some of the hardliner Islamists commanders of Pakistan established their own Jihadist organization under different names, while others were supported by the ISI on a proxy war in Indian occupied Kashmir. The Afghan Jihad left a great influence on the Pakistani people and some of these jihadist groups turned and demanded the enforcement of Shariah Law in the country because of Soviet defeat, Zia-Ul- Haq Islamization processes and Afghan Taliban triumph in Kabul, which encouraged these groups for the implementation of Islamic Law in the country. One of the most important groups among these groups was Tehreek-i-Nifaz-i-Shariat-i-Muhammadi; a group that led the enforcement of Shariah(Islamic) Law in the Malakand division (Marwat \&Toru, 2005).

\section{Background of Bajaur}

Bajaur was part of the former Federally Administered Tribal Areas (FATA) but after the 25th amendment in the constitution of 1973 of Pakistan, the area was merged in Khyber Pukhtunkhwa Province in 2018. It is the smallest district of former FATA in the terms of area, approximately 1290 Square Kilometers and hosting about a Population of 10, 93,684 people. Bajaur is situated in the northwest of Khyber Pukhtunkhwa province and share its boundaries with district Malakand in the southeast, district Dir in Northwest, district Mohmand in its southwest, and sharing a 52-kilometer long border with Afghanistan in its northwest (Consulting, January 3, 2015).

During 1960s, the former Bajaur agency was a subdivision of Malakand Agency and was under the control of Political Agent Malakand, with the passage of time in December 1973, Bajaur was given the status of separate agency and merged in FATA. The status of the Bajaur agency was 
unique because it consisted of three tribal Chiefdoms, i-e, Khar, Nawagai, and Pashat which were under the control of their respective Khans. In the current circumstances, the newly merged District of Bajaur is directly administered by the Provincial Government of Khyber Pukhtunkhwa through Commissioner and Deputy Commissioner. For administrative purposes, the district is further divided into two subdivisions and seven Tehsils headed by Assistant commissioners and each tehsil by a political Tehsildar respectively (Consulting, January 3, 2015).

\section{The Rise of Jihadi Militancy in Bajaur}

The history of Jihadi Militancy in Bajaur traces its roots from the USSR intervention in Afghanistan in late 1979, when the Afghan refugees were hosted near the Pak/Afghan bordering area in tent villages. A large number of refugees were recruited as freedom fighters to resist against the Soviet's occupation in Afghanistan (Haqqani, 2005). Later, in the decade of 1990, the local leaders of seven political parties of Pakistan met union council Maidan District lower Dir on 28 June 28th, 1989, and formed an organization namely Tahrik-e-Nifaz-e-Shariat-e-Muhammadi (TNSM). Sufi Muhammad of Jamat-e-Islami was appointed Nazim-e-Aala (chief) of the movement, and the main purpose of the movement was to solve the problems of local people on their doorstep, because the local Jarga (consultation) system and Provincial Administered Tribal Areas (PATA) regulations were completely failed to cope with the disputes of the local populace. Initially, there were 23 members of the movement and were confined only to District Dir. The hard work of these 23 members bore fruit and the movement was extended to other Districts of Malakand Division including Bajaur and District Kohistan of Hazara Division. In this regard, Sher Bahadur was appointed the first Amir for Bajaur and all the members pledged that they will work collectively to solve all kinds of matters of the localities and started demanding from the government for the implementation of Shariah law in Malakand Division (Uallah, 2013).

To fulfill his dream of the implementation of Shariah law, Sufi Muhammad and his supporters used different tactics on several occasions to compel the government for accepting their demands. When the provincial government didn't accept their demands, Sufi Muhammad summoned the meeting of TNSM central Shura (consultative body) and decided to block the Malakand division and cut the connection of the area from the rest of the province until the government implement Shariah law in Malakand Division. During the blockade, the TNSM activists were hoisting the flags of the movement at Anayat Kallay Bazaar in Bajaur on July 19th, 1994, which were refrained by the Bajaur levies. When the TNSM activists didn't honor warnings, the levies open fire on them and killed three members of the movement, while dozen got severe injuries which turned the situation from bad to worse and later turned to cause chaos in the area (khan, 2010).

\section{Support for Afghan Taliban}

During the Afghan civil war between the Islamists and other warlords, these Jihadis from Pakistan played a vital role to assist the Afghan Islamists and succeed in establishing the Taliban government in Afghanistan in 1996. During the Taliban regime in Afghanistan, many Pakistani militants were given different portfolios in Afghanistan. After the fall of the Taliban regime due to the American invasion in Afghanistan in October 2001, these militants including foreign Jihadists fled to Pakistani Tribal areas and used these areas as safe havens against the coalition forces in Afghanistan. To assist the Afghan Taliban, the TNSM head Sufi Muhammad and other militant commanders' i-e, Maulvi (Muslim religious scholar) Faqeer Muhammad, Dr. Ismail, and Qari (Reader/Reciter) Zia Rehman started recruitment of the local people for Jihad in Afghanistan. To accomplish their goals, they established three F.M Radio channels for mass mobilization and raising funding for the Afghan Taliban. Sufi Muhammad and other militant leaders, not only succeeded in organizing ten thousand volunteer forces of local people from the Bajaur and Malakand division, but also collected about 1.7 million Rupees as economic assistance for the Afghan Taliban (Yousafzai, 2009).

\section{The Rise of Maulvi Faqeer Muhammad and Other Militant Leaders}

Maulvi Faqeer Muhammad, the former Chief of Tehrik-i -Taliban Bajaur and Deputy Chief of Tehriki -Taliban Pakistan was born in 1970 at Chopatra village of Tahsil Mamond District Bajaur. He got his religious education from his hometown under the discipleship of Maulvi Abdusalam and later went to Madrasa (Seminary) namely "Jamaat-e-Ishaat-e-Tahueed-Wa-Shunah" under the shadow 
of Maulana Tahir in PanjPeer at Sawabi Pakistan. After the completion of his religious education, he joined an Islamist political party namely Jamat-i-Islami Pakistan (JIP). 1n 1993, he parted ways with JIP and became one of the core members of TNSM. He was belonging to a Jihadist family and his ancestors fought against the Soviets invaders in Afghanistan, similarly, to follow his ancestor's mission, he also played very key role in the Afghan civil war and fought on two fronts namely Bagram and Panjshir valley, while residing at Kunar province from Taliban's side (Nasir, February13, 2009).

During the Taliban regime, he established good relations with foreigners in Afghanistan and learned the Arabic language with fluency. In November 2001, during the war on terror, he and his mentor Sufi Muhammad organized a volunteer force of ten thousand men and went to Afghanistan along with his two sons. When these untrained volunteers fashion with old gun were unable to compete with the highly sophisticated and trained US Army, they came back to Bajaur with foreign militants of Al-Qaeda, the Islamic Movement of Uzbekistan, and Chechens. In 2005, the security forces of Pakistan raided his house on the suspicion of high-value Al-Qaeda commanders, while in 2006 his house was once again targeted by a missile attack from Americans gunship helicopter on the suspecting presence of Al-Qaeda Deputy Chief Ayman al-Zawahiri, which killed 18 people, while Faqeer Muhammad remained safe. Later, the government of Pakistan with help of the traditional Tribal Jarga (consultation) system burnt his house and he was forced to surrender before the security forces (Nasir, February 13, 2009).

\section{Damadola Mosque Air Strike, Lal Masjid and Jamia Hafsa Operation}

In 2006, the American Air force in Afghanistan attacked a seminary at Damadola in Bajaur Agency on the suspected presence of Al-Qaeda's core members. The American Gunship Helicopters targeted a seminary and according to one estimate, more than 84 students and teachers were killed including TNSM leader Maulvi Liaqat along with TTP leader Fazlullah's Brother Sami Ullah (Yousafzai, 2009). The mourn of Damadola Mosque was not yet cooled that the Musharaf government launched a massive operation against two Mosques i-e Jamia Hafsa and Lal Masjid (Red Mosque) in federal capital Islamabad. During the operation, hundreds of innocent students including their teachers were killed which further deteriorated the situation especially in FATA and sow the seeds of hatred against Pakistan army and America, because the local militants held view that such operation was launched for pleasing the Americans (Shehzad, 2011).

Meanwhile, strong anger arose in Bajaur against the military operations; the militants' leaders started protests against the government. Thousands of local militants under the leadership of Maulvi Faqeer Muhammad pledged for the implementation of Shariah in the area and imposed ban on music in public places like hotels, shops and Bazaars. The people were advised to abandon the business of entertainment instruments like CDS, Cassette, VCRs, Videos cameras and some shops were destroyed with explosive materials. They also banned interest based money lending for being illegal in Islam and imposed taxes on the wealthy people in exchange for the protection of their lives and properties. The militants also established their judicial courts where the issues of disputing parties were resolved (Mahsud, 2012).

In 2008, two militant leaders of Bajaur namely Faqeer Muhammad and Maulvi Omar during a press conference held in Sewai village of Tehsil Mamond formally announced the formation of Tahrik-e-Taliban Bajaur (TTB), Faqeer Muhmmad was nominated as the chief of the Tahrik (movement). Later, with the consent of his colleagues, Faqeer Muhmmad merged Tahrik-i-Taliban Bajaur in Tahrik-i-Taliban Pakistan of Bait Ullah Mehsud and he was elected as the vice chief of TTP Pakistan. During this time period, the Taliban commanders also started collection of extra arms from the local people and advised them to keep just one riffle for their personal security and spare weapons should be given to them. Those who were opposing the Talibanization process were either killed or they fled from the area due to security reasons (Mahsud, 2012). List of the top rank Taliban commanders are described below. 
Table 1. List of Militant Leaders of Bajaur

\begin{tabular}{|c|c|c|}
\hline S.NO & NAMIE & LOCA TIONS \\
\hline 1 & Molvi Faqeer Muhammad & Village Chopatra, Tahsil Mamond District Bajaur \\
\hline 2 & Burhan U Din & Village Damadola, Tahsil Mamond District Bajaur \\
\hline 3 & Moulvi.Inayat ur Rehman & Village Loisam Tahsil Khar District Bajaur \\
\hline 4 & Moulana Syed Jamal u Din, & Village Damadola Tahsil Mamond District Bajaur \\
\hline 5 & Wali Rehman & Village Errab \\
\hline 6 & Haji Naimatullah, & Village Sangar Tahsil Salarzai District Bajawar* \\
\hline 7 & Dr. Ismail, & Village Sewai Tahsil Mamond Distric Bajawar \\
\hline 8 & Moulana Abdullah, & Village Nayag Banda, Tahsil Mamond District Bajaur \\
\hline 9 & MoulanaMuhammad Munir & Village Sewai Tehsil Mamond, District Bajuar \\
\hline 10 & Salar Masood & Village Sewai Tehsil Mamond, District Bajuar \\
\hline 11 & Dr Abdul Wahab & Village Inam Khwaro Chinagai Mamond District Bajaur \\
\hline 12 & Moulana Abdul Hamid, & Village Inam Khwaro Chinagai Mamond District Bajaur \\
\hline 13 & Qari Zia Rehman, & Basically from Afghanistan living Inayat Kalay Bajuar** \\
\hline
\end{tabular}

Source*: Mansur Khan Mahsud; Trends of Militancy in Bajaur Agency in 2011

Source**: Mukhtar A. Khan; A Profile of Militant Groups in Bajaur Tribal Agency

\section{MILITARY OPERATION AND ITS IMPACT}

When the local administration failed to maintain the law and order situation in Bajaur Agency, eventually the military started operation Sher Dil (Line heart) on August 7th, 2008 against the Jihadi militants to expel them from the area. This act of the Pakistani government annoyed the Taliban and as retaliation, they started sabotage activities like suicides attacks on high officials, security forces and public places to restrain the government from taking any adverse action against them (Marwat \& Toru, 2005). The overall impact of Jihadi militancy in Bajaur are discussed below.

\section{Impact on Education Sector}

During the militancy in Bajaur Agency, Taliban destroyed girls' schools by saying that women's education is against the basic principles of Islam and caused vulgarity in the society. So, they blown up 27 girls' schools with explosive materials including high, middles and primary schools, while other 14 schools were partially damaged. Besides, the militants also completely destroyed 65 boys' schools of different levels, and other 23 schools were partially damaged including 2 colleges. Some of these schools and colleges were the result of cross-firing between the militants and army personnel, because the security forces were stationed in these schools for a military operation against them. These incidents seriously affected the academic careers of both boys and girls in the area as they remained deprived for a long period from educations due to continuous curfews, non-availability of educational institutions and threats of terrorist attacks (Mahsud, 2012). The list of completely and partially destroyed schools can be discussed as under:

Table 2. List of Completely Destroyed School in Bajaur during Militancy

\begin{tabular}{|l|l|l|l|l|}
\hline S.NO & High Schools & Middles Schools & Primary Schools & Total Schools \\
\hline Boys Schools & 12 & 8 & 45 & 65 \\
\hline $\begin{array}{l}\text { Girls' } \\
\text { Schools }\end{array}$ & 3 & 3 & 21 & 27 \\
\hline
\end{tabular}

Source*: FATA Research Centre

Table 3. List of Partially Destroyed School in Bajaur during Militancy

\begin{tabular}{|l|l|l|l|l|l|}
\hline S.No & Collages & Fligh Schools & Middle Schools & Primary Schools & Total \\
\hline Boys Schools & 2 & 6 & 5 & 10 & 23 \\
\hline $\begin{array}{l}\text { Girls' } \\
\text { Schools }\end{array}$ & 0 & 2 & 1 & 11 & 14 \\
\hline
\end{tabular}

Source*: FATA Research Center 


\section{Human loss and casualties}

The seeds of Jihadi militancy, sown by Maulvi Faqeer Muhammad and his brigade in Bajaur Agency not only destroy the peaceful environment of the area, but also snatched lives from many people. In this regard, bloodshed occurred during militancy and approximately 1151 incidents of sabotage activities like i-e fatalities, suicide attacks, and bomb blasts were took placed, resulted in the death of 6656 people including militants, military personnel, and innocent local people, 1786 were seriously injured. The details of sabotaged activities can be discussed as follow:

Table 4 Human Loss in the Term of Assassination, Suicides Attacks and Bomb Blasts in Bajuar

\begin{tabular}{|c|c|c|c|c|c|c|c|}
\hline S.NO & $\begin{array}{l}\text { Incid } \\
\text { ents }\end{array}$ & Civilians & $\begin{array}{l}\text { Security } \\
\text { Forces }\end{array}$ & Militants & $\begin{array}{l}\text { Not } \\
\text { Specified }\end{array}$ & Injuries & Deaths \\
\hline Fatalities & 635 & 500 & 201 & 2695 & 41 & NS & 3437 \\
\hline $\begin{array}{l}\text { Major } \\
\text { Incidents }\end{array}$ & 228 & 326 & 145 & 1934 & 25 & 810 & 2430 \\
\hline $\begin{array}{l}\text { Suicide } \\
\text { Attacks }\end{array}$ & 11 & 127 & 18 & 14 & 0 & 252 & 159 \\
\hline Bomb Blasts & 277 & 288 & 84 & 252 & 6 & 724 & 630 \\
\hline Total & 1151 & 1241 & 448 & 4895 & 72 & 1786 & 6656 \\
\hline
\end{tabular}

Source*: South Asian terrorism Portal (SATP)

\section{Internally Displaced Persons (IDPs)}

During the anarchic situation and absence of the government writ, Bajaur was on the mercy of Taliban, tribal leaders and Maliks(Chieftains) who opposed the Talibanization process were killed with brutality. Due to security measurements and life threats, many notables, stakeholders and prominent Maliks left their areas, while on the other hand, the military decided to start a decisive operation against the militants to restore the writ of the government and to annihilate the safe havens of militants in Bajaur. To avoid the casualties of innocent people and minimum damage, the military ordered the local masses to vacate their houses before the operation. As a result, two lac and fifty thousand $(25,0000)$ including men, women, young and old people fled to safer places in district Dir lower, Malakand, Mardan, Peshawar district and other parts of the country where they lived as IDPs (Khalid \& Roy, 2016).

\section{Impact on Trade and Business}

Trade and Business are very useful for a county's economic development and prosperity but due to militancy, this sector suffered very huge loss. At the initial stages, the militants blew the CD Cassettes, and TVs shops with explosive materials, and later during the military operation, approximately 5000 thousand shops in different Tehsils of Bajaur were completely destroyed. The most affected Bazar (emporium) was Anayat Kally, where about 2400 shops were destroyed. While other affected areas including Tehsil Khar, Salarzai, Mamonde, Nawagai, Laghari, Siwai, and Charming, where 300 hundred shops in each area were destroyed by the mortars, artillery shillings, or by jet bombing during the operation in Bajaur. According to one estimate, the wroth of average shop was about 15 to 20 lac, while some other were in millions. Besides, due to a long period of curfew and displacement from the areas, the remaining safe shops were also affected due to the expiration of households. It must be noted that the number of partially and completely destroyed shops may be more than estimation (Ullah, 2021).

\section{Impact on Livestock and Poultry}

Livestock and Poultry farming is one of the best income-generating sources of the local people of Bajaur, low-income families of the rural areas of Bajaur were relying on livestock and poultry farms to meet their household needs, avoid unemployment, and feed the stomach of their families. The major portion of local inhabitants are attached to the business of livestock and poultry farms. There were about 15 to 20 poultry farms in different Tehsils of Bajaur, and their approximated worth was about 15 to 20 lac each, but unfortunately during militancy and military operation, this sector was badly affected. Due to the sudden evacuations from the area, the people left their farms and houses 
and fled for safer places to protect themselves, and majority of the poultry and cattle like sheep, goats, cows, and buffalos were died of hunger, thirst or were hunted by the hungry dogs of the areas. While some poultry farms and other cattle became the target of artillery, mortar shelling or Jet Bombardments, which not only weakened the economic position but also increased the poverty level of the local inhabitants (Ullah, 2021).

\section{Impact on Agriculture}

Horticulture is to be considered as the backbone of a country's economy and playing a very vital role in boosting per capita income of the inhabitants. Pakistani society is agro-based and the majority of the people are connected with horticulture, but due to militancy and military operation in Bajaur, this sector was badly inflicted. The military operation was started at a time when the harvesting of maize crops was to begin, but due to security reasons, the people left their crops and fled. According to one estimate, the whole maize, rice, tobacco crops and fodder were spoiled, and other crops like Wheat were not cultivated because the people were IDPs in different areas of NWFP. Similarly, large number of orchards of oranges, plums, peaches, apricots, and persimmons, which not only could fulfill the personal needs of local inhabitants but also imported to the rest of the country, were badly affected by militancy (Ullah, 2021).

\section{Impact on Marble Factories and Houses}

Bajaur is famous for marbles granites, chromite and other natural resources. According to the marble factories association president Tufail khan, there were 18 to 22 marble factories in Bajaur and about 12 to 15 labors were working in each factory to meet their daily needs. During the military operation, these factories remained unsafe due to the ongoing war between the military and militants as these marbles factories were situated in hilly areas where the Taliban were fighting against the security forces. While on the other side, the military was targeting the safe havens of militants with artillery, mortars shelling, and Jet bombardments. Most of the factories were shut down due to security reasons, and the workers became unemployed and migrated to safer places. During the interview, it was also identified that more than 500 hundred houses were also destroyed during the military operation in Bajaur (Ullah, 2021).

\section{CONCLUSION}

This study concludes that militancy in the Bajaur Agency of Pakistan led by Maulvi Faqeer Muhammad and other prominent leaders of Tahrik-i-Taliban Bajaur traced its roots from the Soviet invasion in Afghanistan in late 1979. The triumph of Afghan Taliban in civil war in 1996 encouraged the Jihadists militant groups in Pakistan to implement Shariah law in the country. After the 9/11 incident and American Invasion in Afghanistan, many Pakistani and foreigners Jihadists fled from Bajaur Agency of Pakistan and established Illegal F.M radio stations for mass mobilization. The militants were praising the importance of Jihad and succeed to recruit large number of Jihadists in the area; military training camps were established for Jihadist zeal. In the first phase of militancy, Taliban imposed ban on female education, musical shows and musical instruments; local people were disarmed and Shariah courts were also established where the disputes of the people were resolved. Those who were opposing the Taliban style of Shariah including Maliks, notables, stakeholders, paramilitary forces, army and local administration personnel were killed with brutality. It is also concluded from the study that during the military operation against the Jihadists militants in Bajaur, more than 250000 people became IDPs in other parts of Khyber Pukhtunkhwa. During the Jihadi militancy and military operation in Bajaur, the collateral damages report revealed that 92 schools of both boys and girls were completely destroyed, while the other 37 including 2 colleges were partially damaged. Besides, heavy losses were also reported in the form of severe damages to educational institutions, houses, agriculture, livestock, poultry farms, and small-scale industries. The Jihadi militancy and its impact not only debilitated the life standard of local inhabitants of the area but also left indelible imprints on the socio-economic and political lives of the local residents of Bajaur. 


\section{REFERENCES}

Abbas, H. (2005). Pakistan drifts into extremism. Routledge.

Consulting, A. (January 3, 2015). Development profile of Bajaur Agency. Pakistan Poverty Alleviation Fund (Ppaf).

Haqqani, H. (2005). Pakistan between Mosque and military. Vanguard Publishers.

Khan, N.I. (2010). Tahrik-i-Nifaz-i-S Hariat-i- Muhammadi in Malakand Division: A case study of the process of the state inversion. Pakistan Journal of History and Culture, XXXI (1), 131158.

Kretsch, A. (2016). The misconception of jihad in America. Undergraduate Library Research, 1- 15.

Mahsud, M.K. (2012). Trends of militancy in Bajaur Agency in 2011. FATA Research Center.

Nasir, S.A. (2009). Al-Zawahiri's Pakistani ally: profile of Maulana Faqqeer Muhammad. Terrorism Monitor the Jamestown Foundation, 125-150.

Rehman, Fazal Ur \& Teru P, K. (2005). Talibanization of Pakistan: A case study of TNSM, Peshawar: Pakistan Study Center University of Peshawar.

Roy, I.K. (2016). Pakistan's military operations: The counter terrorism strategy (2001-2013) prospects and implications. Journal of the Research Society of Pakistan, 53(2), 239-253.

Shehzad, S. (2011). In side Al-Qaida and the Taliban. Pluto Press.

Ullah, K. (2013, 5 May). Formation of TNSM and their activities. (B. Sardar, Interviewer)

Ullah, K. (2021, 19 June). Impact of Military Operation on Bajaur. (H. M. Sufi, Interviewer)

Ullah, K. (2021, 18 June). Impact of Militancy on Marble Factories. (T. Khan, Interviewer)

Yousafzai, A. (2009). Talibanization from Afghanistan to FATA, Swat and Pakistan. Nigaar Publishers. 